\title{
Survey for Purple Blotch Disease of Onion (Allium cepa L.) in Cited by Alternaria porri (Ellis) Cifin Different Regions of Tamil Nadu
}

\author{
R. T. Nivithaa Shree ${ }^{1}$, K. Kalpana ${ }^{1 *}$, E. G. Ebenezar ${ }^{2}$, M. Theradimani ${ }^{1}$, \\ S. Thiruvudainambi ${ }^{1}$ and S. Vellaikumar ${ }^{3}$
}

${ }^{1}$ Department of Plant Pathology, ${ }^{3}$ Department of Biotechnology, Agricultural College and Research Institute, Tamil Nadu Agricultural University, Madurai, Tamil Nadu, India

${ }^{2}$ Department of Plant Pathology, Agricultural College and Research Institute, Tamil Nadu Agricultural University, Killikulam, Tamil Nadu, India

*Corresponding author

\section{A B S T R A C T}

\section{Keywords}

Onion, Purple blotch, A. porri, Pathogenicity etc.

\section{Article Info}

\section{Accepted:}

04 November 2020

Available Online:

10 December 2020
Onion (Allium cepa L.) is an important bulbous vegetable crop grown all over the world and known for its pungency and flavor. Onion production is affected by various diseases. Among the diseases, purple blotch caused by Alternaria porri (Ellis) Cif is one of the major destructive diseases and cause damage to both foliage production and also bulb yield. A survey was carried out in major onion growing areas of Tamil nadu viz., Dindugal, Permabalur, Theni, Madurai, Salem, Dharmapuri and Krishnagiri districts. The highest purple blotch severity of 60.8 percent disease index (PDI) was observed at Andipatti village in Theni district, less severity of 29.5 percent PDI was noticed in Periyamuthoor area of Krishnagiri district. Isolation was made from infected onion leaves which showed prominent purple blotch symptoms. Pure culture of fungal pathogen $(A$. porri) was obtained and its pathogenicity was proved on onion plants. The isolated pathogen was confirmed as Alternaria porri (Ellis) Cif. based on the fungal culture morphology and its pathogenicity on onion plants.

\section{Introduction}

Onion (Allium cepa L.) is an herbous crop which is commercially cultivated worldwide. It belongs to the family Alliaceae and widely used as vegetable, spice and salad. Owing to its therapeutic and nutritive value, onion is often known as "queen of kitchen". It is highly rich in sulfur, potassium, vitamin B6, iron, vitamin $\mathrm{C}$, anthocyanin and antioxidant particularly quercetin (Cramer 2000). The productivity of onion is pretended by numerous fungal and bacterial diseases viz., Purple blotch, twister blight, downy mildew, stemphylium blight and bacterial soft rot are known to cause more substantial yield loss to the crop. Among these foliar diseases, purple blotch disease caused by Alternaria porri (Ellis) Cif. is one of the most disastrous disease in all onion growing regions of the world, which is limited to the genus Allium(Kareem et al., 2012). In India, 
Alternaria was first reported by Ayyanagar (1928) in Bellary onion leaves. Severity of the disease may vary based on locality, variety and season. The disease incidence was less prevalent in Rabi season when compared with Kharif season. Under the favourable environmental condition of high relative humidity $(80$ to $90 \%)$ and optimum temperature $\left(24+2^{0} \mathrm{C}\right)$ can cause yield loss upto $30-100 \%$ (Yadav et al., 2017). Now-adays many fungicides have been applied to manage the purple blotch disease of onion but it is failed to inhibit the pathogen due to establishment of new races of pathogen. So, survey is one of the effective plant protection strategy to manage the disease timely and also promptly. Keeping all these aspects in view, the present study focused the eye on survey and assessment the disease incidence in major onion growing regions of Tamil Nadu.

\section{Materials and Methods}

\section{Collection of infected leaf sample through survey}

The survey was conducted at different districts of Tamil Nadu viz., Dindugal, Permabalur, Theni, Madurai, Salem, Dharmapuri and Krishnagiri district. Then infected onion leaf samples from surveyed field was collected in brown paper cover and taken into the laboratory, Department of Plant Pathology at Agricultural College and Research Institute, Madurai. The disease severity was scored by following 0-5 scale as given by Sharma (1986). The details of scales are as shown below.

0 - No disease symptoms.

1 - A few spots towards tip covering 10 per cent leaf area

2 - Several dark purplish brown patch covering upto 20 per cent leaf area

3 - Several patches with paler outer zone covering upto 40 per cent leaf area
4 - Leaf streaks covering upto 75 per cent leaf area or breaking of the leaves from center

5 - Complete drying of the leaves or breaking of the leaves from center

The per cent disease index (PDI) was assessed by using following formula given by McKinney (1923)

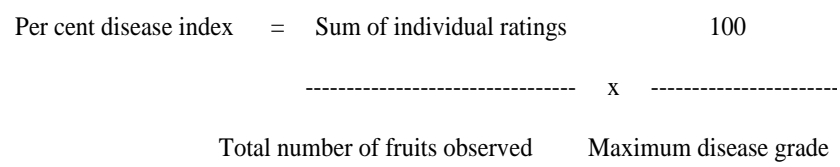

\section{Isolation of the pathogen}

The pathogen $A$. porri was isolated from the diseased onion leaves using tissue segment technique. The infected leaves were selected and cut into small bits of about $2 \mathrm{~mm}$ diameter and surface sterilized the leaf bits with $1 \%$ sodium hypochlorite for 20 mins. Then the cut leaf bits were rinsed with sterile distilled water for three times to eliminate the traces of sodium hypochlorite, dried on sterile tissue paper then transferred the disinfected leaf bits on the Petri plates which contain 15 $\mathrm{ml}$ of Potato Dextrose Agar medium (PDA) in laminar air flow chamber and incubated the plates at $25^{\circ} \mathrm{C}$ for ten days. The plates were observed frequently for fungal growth. After ten days fungal colonies developed from the infected leaf bits were transferred to PDA slants. The well grown fungal culture was purified by single spore suspension technique.

\section{Single spore isolation}

Ten milli litre of sterilized water agar was poured into Petri plates and allowed to solidify. Spore suspension was prepared using sterile distilled water from ten days old culture. One milli litre of spore suspension was poured to Petri plates uniformly, again 2 $\%$ agar was poured aseptically and allowed to solidify. Then the plates were observed under compound microscope to view the pathogenic 
conidia. Single isolated conidium was then marked under the microscopic field with ink on the surface of the Petri plate. Then the marked areas were cut and transferred aseptically onto PDA slants with the help of cork borer and incubated at $28 \pm 10^{\circ} \mathrm{C}$.

\section{Pathogenicity study}

Onion seedlings (30 days old) was plantedin the earthern pots which contain mixture of sandy loam soil and cowdung (4:1) in glasshouse. The plants were sprayed with distilled water and covered using polythene bags for $24 \mathrm{hr}$. The spore (conidia) suspension of $A$. porri was prepared from 10 days old fungal culture using sterile distilled water at the concentration of $10^{8}$ spores $/ \mathrm{ml}$. Then, onion leaves were punctured using sterile toothpick. After that pathogenic spore suspension was sprayed onto the injured leaves of 30 days old plants.

The inoculated plants were covered with polythene bags and incubated for 3-4 days to maintain relative humidity and also for easy penetration of the conidia into the leaves. The polythene bags were removed after 5 days and inoculated plants were kept under glasshouse. The plants were observed regularly for symptom expression. After the appearance of disease symptoms, re-isolation was made from the diseased tissues of artificially inoculated plants. The isolate obtained was compared with the original culture for confirmation of fungus.

\section{Results and Discussion}

\section{Survey for the occurrence of onion purple blotch disease}

A survey was conducted for assessing the disease severity in onion in different regions of Tamil Nadu viz., Dindugal, Permabalur, Theni, Madurai, Salem, Dharmapuri and Krishnagiri district.
The survey for distribution, symptomatology, and severity of onion purple disease was recorded and the data was presented in the Table 1. The survey results showed that incidence of the disease in different regions and severity ranges from 29.5 to 60.8 percent disease index (PDI) in different districts of Tamil Nadu. The highest purple blotch severity of 60.8 PDI was observed at Andipatti village in Theni district (Figure 1) followed by 58.4 percent disease index was recorded in the fields of Alanganallur village in Madurai district, least severity 29.5 PDI was noticed in Periyamuthoor area of Krishnagiri district. The average disease incidence of about 47.0 PDI was recorded in Padalur village in Perambalur district followed by 45.1 PDI was observed at Ottanchathiram area of Dindugul district.

Working on survey of purple blotch disease of onion, Patil and Patil (1992)reported that it is the major severe and most prevalent disease in the onion growing areas of Maharashtra. Srivastava and Gupta ( 2006)recorded occurrence ofpest and diseases of onion in India and also observed that disease severity was more in rainy as well as post-rainy seasons when high $\mathrm{RH}$ prevailed. The findings by Chethana (2000)who conducted survey during Kharif (1999) in the Northern parts of Karnataka also concluded that purple blotch disease occurrence was observed almost all districts of Karnataka and noticed the highest per cent disease index (PDI) in the Ronihal village of Bijapur district and lowest PDI was recorded in Wadullur village of Raichurtaluk. Patilkulkarni (2013) surveyed at all areas of Northern Karnataka during Kharif (2012-13) and reported that purple blotch incidence was little severe in Haveri district.

During survey various purple blotch disease symptoms were observed both on bulbs as well as leaves (Fig. 2 and 3). The older leaves were more susceptible to infection. Initially, oval to elliptical water soaked lesion appeared 
on the leaves which later gets progressed and forms discoloured tissue around the spots. Spots were white initially and later turns to light purple or pink. The colour change emerge from center to progress towards the periphery region and completely turns to purplish in color. During change in colour, concentric rings can be seen easily through naked eye. The disease symptoms were documented in the infected field and presented in the figure 4 .

Table.1 Distribution of purple blotch disease of onion incited by Alternaria porri in major onion growing regions of Tamil Nadu

\begin{tabular}{|c|c|c|c|c|c|}
\hline S.No. & Districts & Location & $\begin{array}{l}\text { Isolate } \\
\text { code }\end{array}$ & $\begin{array}{l}\text { Geographic } \\
\text { coordinates }\end{array}$ & $\begin{array}{l}\text { *Percent disease } \\
\text { index (PDI) }\end{array}$ \\
\hline \multirow[t]{2}{*}{1.} & \multirow[t]{2}{*}{ Perambalur } & Anukur & IS Ak & $\begin{array}{l}11.3315^{\circ} \mathrm{N} \\
78.8623^{\circ} \mathrm{E}\end{array}$ & $\begin{array}{c}53.2 \\
(43.86)\end{array}$ \\
\hline & & Padalur & IS Pd & $\begin{array}{l}11.1063^{\circ} \mathrm{N} \\
78.8447^{\circ} \mathrm{E}\end{array}$ & $\begin{array}{c}47.0 \\
(45.63)\end{array}$ \\
\hline 2. & Theni & Andipatti & IS Th & $\begin{array}{l}10.0015^{\circ} \mathrm{N} \\
77.6164^{\circ} \mathrm{E}\end{array}$ & $\begin{array}{c}60.8 \\
(39.85)\end{array}$ \\
\hline 3. & Dindugul & Ottanchathiram & IS Ot & $\begin{array}{l}10.4897^{\circ} \mathrm{N} \\
77.7544^{\circ} \mathrm{E}\end{array}$ & $\begin{array}{c}45.1 \\
(40.76)\end{array}$ \\
\hline \multirow[t]{3}{*}{4.} & \multirow[t]{3}{*}{ Madurai } & Alanganallur & IS Al & $\begin{array}{l}10.0474^{\circ} \mathrm{N} \\
78.0904^{\circ} \mathrm{E}\end{array}$ & $\begin{array}{c}58.4 \\
(47.35)\end{array}$ \\
\hline & & Palamaedu & IS Pm & $\begin{array}{l}10.1043^{\circ} \mathrm{N} \\
78.1130^{\circ} \mathrm{E}\end{array}$ & $\begin{array}{c}33.7 \\
(38.71)\end{array}$ \\
\hline & & Malayalathampatti & IS Mp & $\begin{array}{c}9.9634^{0} \mathrm{~N} \\
78.2081^{0} \mathrm{E}\end{array}$ & $\begin{array}{c}36.1 \\
(39.27)\end{array}$ \\
\hline 5. & Coimbatore & Lawley road & IS Lw & $\begin{array}{l}11.0124^{\circ} \mathrm{N} \\
76.9409^{\circ} \mathrm{E}\end{array}$ & $\begin{array}{c}48.3 \\
(46.02)\end{array}$ \\
\hline 6. & Krishnagiri & Periyamuthoor & IS Pr & $\begin{array}{l}12.518611^{\circ} \mathrm{N} \\
78.213737^{\circ} \mathrm{E}\end{array}$ & $\begin{array}{c}29.5 \\
(23.62)\end{array}$ \\
\hline \multirow[t]{2}{*}{7.} & Salem & Vazhapadi & IS Vp & $\begin{array}{l}11.6555^{\circ} \mathrm{N} \\
78.4013^{\circ} \mathrm{E}\end{array}$ & $\begin{array}{c}37.6 \\
(40.78)\end{array}$ \\
\hline & \multicolumn{4}{|c|}{$\mathrm{CD}(\mathrm{P}=0.05 \%)=1.08$} & \\
\hline
\end{tabular}

Fig.1 Severity of purple blotch of onion in Theni district - Field view

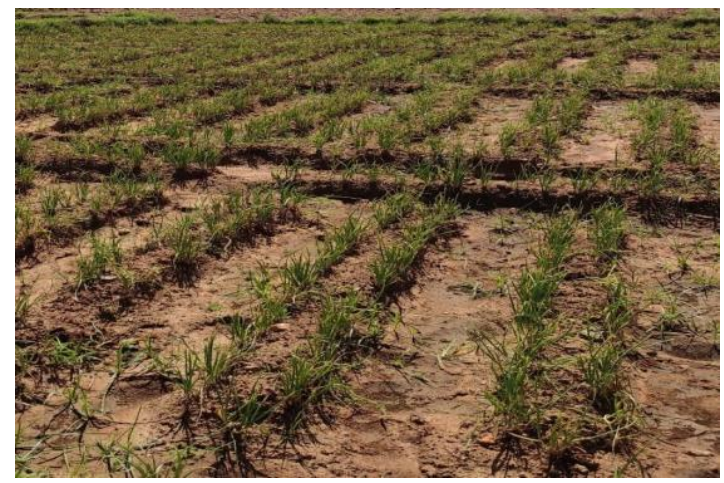


Fig.2 Severity of purple blotch disease of onion in Krishnagiri district

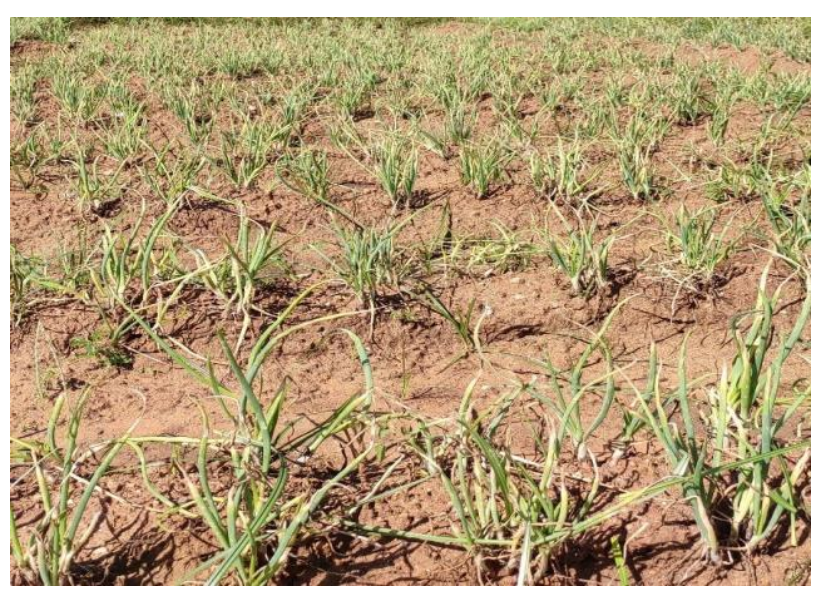

Fig.3

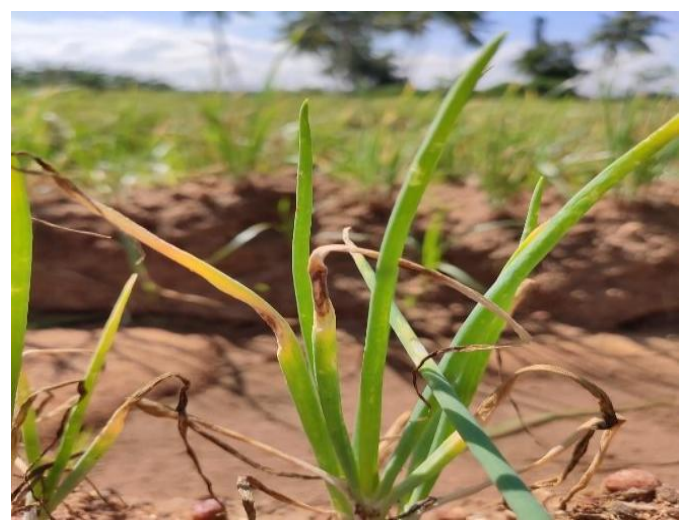

Fig.4 Symptoms of purple blotch of onion caused by Alternaria porri
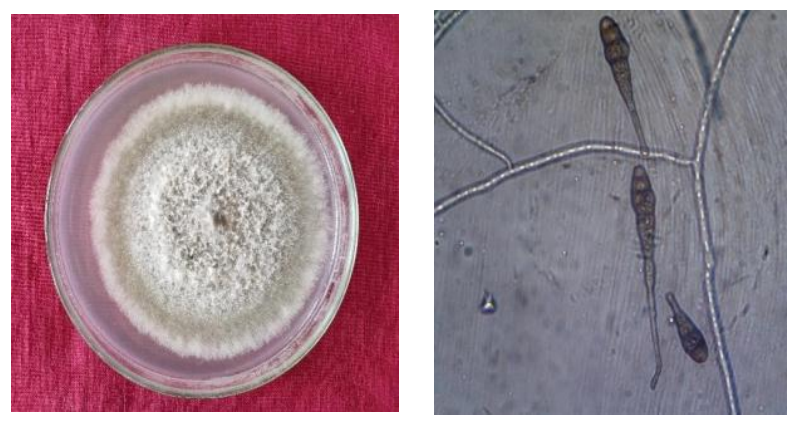

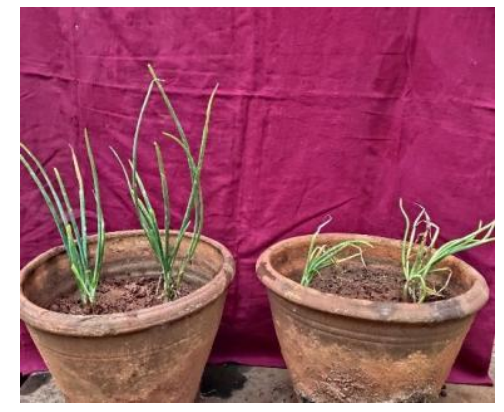

and methods. The pure culture was obtained after single spore isolation. The fungal culture was noticed after seven days of inoculation which initially produced whitish growth and later turn to grayish in color. The pure culture was again sub- cultured on potato dextrose 
agar (PDA) slants and stored in refrigerator at $4^{\circ} \mathrm{C}$ for further study. The pure fungal culture was obtained from tissue isolation method and they also explained about new technique for inoculum preparation and finally concluded that spore suspension was the most effective inoculum for culture development (Dhiman and Chadha, 1986).

\section{Identification of pathogen}

The fungal pathogen was identified based on the morphological characters of the pathogen. The fungus produced coloured, septate mycelium. The conidiophores may arise either singly and rarely forms small groups. The conidiophores were septate, pale golden brown in color straight or flexuous and sometime geniculate with one or few conidial scars. A matured conidiophore generally produced as single conidium but, rarely it also produces very short chains, straight or slightly curved, light brown to golden brown in color, beak generally equal to the body size of the conidium which produces transverse (7 to 9) and longitudinal (zero to few) septations. The characters of our pathogenic culture were strongly agreed with those of pathogen $A$. porri explained by Cifferi (1930)and Ellis (1971)with few variation in size and shape which may lack due to environmental conditions in corresponding regions.

\section{Assessing the virulence of the pathogen}

For proving pathogenicity on onion host, the pathogen $(A$. porri) was artificially inoculated on the onion leaves. The symptoms started to appear on inoculated onion leaves at eight days after inoculation. The symptoms appears as a small, water soaked lesions which later enlarges and became sunken, purplish in color along with concentric rings and surrounded by yellow halo. The typical symptoms were noticed after 30 days of inoculation and leaves completely turns to purplish color on the onion leaves. In the present study, disease symptoms given above were agreed with the typical symptoms described by earlier workers Ponnappa (1974); Utikar and Padule (1980); Patil and Patil (1992); Chethana (2000) they proved pathogenicity on onion plants by spraying spore suspension on the plant surface. The pathogen was re-isolated from artificially infected leaves and compared with the original culture. Hence, finally confirmed that Alternaria porri (Ellis) Cif. as the causal agent of the purple blotch disease of onion.

\section{References}

Ayyanagar, C. R. 1928. A leaf spot and blight disease of onions caused by Alternaria palandui sp. nov. Agric. Res. Inst. Pusa Bull., 179:141-179.

Chethana, BS. 2000. Studies on Alternaria leaf blight of onion (Allium cepa. L). University of Agricultural sciences, GKVK Bangalore.

Cifferi, R. 1930. Phytopathological survey of Santo Domingo, 1925- 1929. J. Porto Rico. 14 (Department of Agriculture (USA),):5-44.

Cramer, Christopher S. 2000. Breeding and genetics of Fusarium basal rot resistance in onion. Euphytica 115 (3):159-166.

Dhiman, JS, and ML Chadha. 1986. Studies on artificial creation of purple blotch epiphytotics in onion for identifying source of resistance.

Ellis, MB. 1971. Dematiaceous Hyphomycetes. Commonwealth Mycological Institute, Kew, Surrey, England.

Kareem, M A, K V Murthy, H A Nadaf, and MA Waseem. 2012. Effect of host age and inoculum concentration on disease severity of purple blotch of onion caused by Alternaria porri. International Journal of Plant Protection 5 (1):93-95. McKinney, HH. 1923. A new system of 
grading plant diseases. J. Agric. Res 26 (2):195-218.

Patil, AO, and BC Patil. 1992. Leaf blight of onion caused by Alternaria state of Pleospora infectoria. Journal Maharastra Agricultural universities 17:353-353.

Patilkulkarni, V G. 2013. Organic Management of Purple Blotch of Onion Caused by Alternaria porri (Ellis) Cif. UAS, Dharwad.

Ponnappa, K. M. 1974. Leaf blight of onion (Allium cepa) caused by Alternaria cepulae Ponnappa and Deshpande. . Blihefte Zur Nova Hadwigia, 47:547564.

Sharma, SR. 1986. Effect of fungicidal sprays on purple blotch and bulb yield of onion. Indian Phytopathology 39 (1):78-82.

Srivastava, K. J., and R. P. Gupta. 2006. Disease of onion and Garlic, NHRDF, Nasik.:55pp.

Utikar, PG, and DN Padule. 1980. A virulent species of Alternaria causing leaf blight of onion. Indian Phytopathology, 33(2): 335-336.

Yadav, Ritesh Kumar, Amarjit Singh, Sandeep Jain, Madhav Pandit, and Rajeev Dhakal. 2017. Physiological studies on Alternaria porri and Stemphylium vesicarium causing purple blotch complex in onion. Horticultural Biotechnology Research: Pp. 13-21.

\section{How to cite this article:}

Nivithaa Shree, R. T., K. Kalpana, E. G. Ebenezar, M. Theradimani, S. Thiruvudainambi and Vellaikumar, S. 2020. Survey for Purple Blotch Disease of Onion (Allium cepa L.) in Cited by Alternaria porri (Ellis) Cifin Different Regions of Tamil Nadu. Int.J.Curr.Microbiol.App.Sci. 9(12): 323-329. doi: https://doi.org/10.20546/ijcmas.2020.912.042 